From the Development Cooperation Bureau,

Royal Veterinary and Agricultural University, Copenhagen, Denmark.

\title{
Comparative Characterization and Biotyping of Staphylococcus aureus Isolates from Human and Bovine Sources
}

\author{
By Ibrahim O. Farah, Erik Pedersen, Christian Halgaard and Kaj Bruhn
}

Farah, I. O., E. Pedersen, C. Halgaard and K. Bruhn: Comparative characterization and biotyping of Staphylococcus aureus isolates from human and bovine sources. Acta vet. scand. 1988, 29, 303-310. - One Hundred and ten alpha and/or delta-haemolytic isolates (collection 1), 50 beta haemolytic isolates (collection 2) from bovine mastitis, and 100 previously phage-typed alpha- and delta-haemolytic isolates (human collection) og Staphylococcus aureus (S. aureus) were tested and biotyped according to the scheme of Hajek \& Marsalek (1971).

Among collection 1 isolates, 85 (77.3 \%) belonged to the human biotype A (human source). Twenty two $(20 \%)$ designated as non-allotted strains, possessed characteristics of both animal and human sources. The remaining 3 isolates $(2.7 \%)$ in this collection belonged to biotype $\mathrm{C}$ (animal source).

All collection 2 isolates which were used as control strains for animal sources, belonged to biotype $\mathrm{C}$.

The human collection that contained 100 phage-typed haemolytic isolates (representing all human phage groups) were used as a control for the human source. Irrespective of their phage group, these strains predominantly produced alpha and/or delta haemolysins and belonged to the human biotype $\mathrm{A}$.

This study also recommended the use of a combined plasma crystal violet agar medium for the presumptive identification of $S$. aureus biotypes.

mastitis; bacteriophage; non-allotted strains.

\section{Introduction}

Infections due to staphylococci are of considerable importance to both human and veterinary practices. The incidence of these infections has increased due to the difficulty of their control (Cohen 1972, Devriese \& Oeding 1976, Adekeye 1980). Notable among the diseases produced by this organism in cattle is bovine mastitis (Riche et al. 1973, Witte et al. 1978).

The adverse effects of mastitis on the economy and public health are well documented (Mohan et al. 1973, Janzen 1970, Adekeye 1980). Consumption of milk and/or milk products by human beings from animals affected with mastitis may under unfavourable circumstances lead to food poisoning. Moreover, transmission of antibiotic-resistant strains from animal to humans and vice versa could also occur, resulting in serious economic and public health implications.

In view of the importance of the identification of the source of staphylococcal infections to achieve efficient control, the present study was undertaken on haemolytic $S$. aureus strains isolated by the National Vete- 
rinary Laboratory, Ringsted, and the State Serum Institute, Denmark.

The objective was to test three collections according to the biotyping criteria for differentiating the human and animal strains of $S$. aureus to detect any human - animal source relationship and the extent of its influence on infection in cows, and to devise a simplified and practical method to presumptively differentiate $S$.aureus isolates from different sources. The choice of alpha and delta haemolytic strains was made in the present study because these haemolytic strains bear some characteristic relevance to the human isolates of $S$. aureus.

\section{Material and methods}

Sources of the isolates

One hundred and ten isolates of $S$. aureus producing alpha and/or delta haemolysins designated as collection 1 , and 50 beta haemolytic isolates designated as collection 2, were obtained from the mastitis laboratory at Ringsted, Denmark.

One hundred human isolates, representing 4 phage groups namely, I, II, III, an M, each consisting of 25 strains designated as the human collection, were obtained from the Department of Hospital Infections, State Serum Institute (SSI), Copenhagen, Denmark.

\section{Media}

To biotype the strains, 3 media namely, blood agar, fibrinolysin agar, and crystal violet agar (CVA) were used. The BactoCrystalviolet medium ( $1: 10000)$ was combined with $12 \%$ fresh human or bovine plasma (Dept. of Hospital Infections, SSI, and the National Veterinary Laboratory, Ringsted, Denmark, respectively) was used as a modified test medium for presumptive identification of $S$. aureus biotypes (Christie \& Wilson 1941, Klastrup 1955, Meyer 1967).

\section{Coagulase test}

This test was performed as described by the Subcommittee on Taxonomy of Staphylococci (1965).

\section{Haemolysis}

The haemolysis production was tested on $5 \%$ sheep blood agar, and was interpreted as follows:

1. A narrow zone af clear haemolysis without clear edges around the colony was declared alpha haemolysis.

2. A wider clear zone around the colony with clear demarcated edges was called delta haemolysis.

3. Incomplete haemolysis which would clear upon incubation in the refrigerator was identified as beta haemolysis.

Further confirmation of the beta haemolysis was done by the reverse CAMP test (Cruickshank 1975). Combinations of the above patterns were also recorded as alpha delta, and alpha beta delta haemolyses.

\section{Biotyping}

The biotyping was carried out according to the method of Hajek \& Marsalek (1971), Devriese (1984). Phage typing was done at the Dept. of Hospital Infections, SSI, Denmark, according to the method of Blair \& Williams (1961), using the International set of phages, and phage 42D of the bovine phage set.

The criteria for biotyping were fibrinolysis of human plasma, pigmentation, coagulation of human plasma, production of alpha or beta haemolysis, crystalviolet type and the typability with the human and bovine phage sets. According to this, $S$. aureus was subdivided into 6 biotypes A through $\mathrm{F}$ ( $\mathrm{Ha}$ jek \& Marsalek 1971).

Biotype A represented the human source of origin, biotype $\mathrm{B}$ the swine and poultry, biotype $\mathrm{C}$ the bovine and ovine, biotype $\mathrm{E}$ the 
canine and equine, and biotype $\mathrm{F}$ was from pigeons.

Presumptive detection of $S$. aureus biotypes The human and bovine plasma crystal violet plates were used in conjunction with each other to identify 260 isolates already biotyped according to Hajek \& Marsalek (1971).

\section{Results}

Table 1 shows the results on biotyping of the 3 groups of $S$. aureus isolates.

One of the 110 bovine mastitis isolates (collection 1), 85 (77.3 \%) belonged to biotype $\mathrm{A}$ and $3(2.7 \%)$ to biotype $\mathrm{C}$. The remaining 22 isolates $(20 \%)$ did not belong to either of the biotypes (non-allotted).

All the human collection isolates were found to belong to biotype $\mathrm{A}$ irrespective of their phage group.

The 50 beta haemolysin-producing isolates (collection 2) all belonged to biotype $\mathrm{C}$.

The summary of the biocharacteristics of the 3 collections of $S$. aureus is presented in Table 2.

\section{Phage-typing of collection 1 isolates}

Phage-typing with group IV, phage 42D: It was found that only 3 strains from bovine group 1 were sensitive to this phage indicating their animal origin, whereas the rest were not sensitive (Table 3 ).

Phage-typing with the human phage groups: Table 3 shows the pattern and frequency of the phage types of bovine collection 1 isolates of $S$. aureus. Most of these patterns are similar to the human phage types.

Table 1. Classification of three groups of $S$. aureus into biotypes.

\begin{tabular}{|c|c|c|c|c|}
\hline \multirow[b]{2}{*}{$\begin{array}{l}\text { Source } \\
\text { tested }\end{array}$} & \multicolumn{4}{|c|}{ Typical reactions of biotypes } \\
\hline & A & c & $\begin{array}{l}\text { non- } \\
\text { allotted }\end{array}$ & $\begin{array}{c}\text { Total } \\
\text { no. }\end{array}$ \\
\hline $\begin{array}{l}\text { Bovine mastitis } \\
\text { (collection 1) }\end{array}$ & 85 & 3 & 22 & 110 \\
\hline $\begin{array}{l}\text { The human collecti } \\
\text { Phage } \\
\text { group I }\end{array}$ & 25 & 0 & 0 & 25 \\
\hline $\begin{array}{l}\text { Phage } \\
\text { group II }\end{array}$ & 25 & 0 & 0 & 25 \\
\hline $\begin{array}{l}\text { Phage } \\
\text { group III }\end{array}$ & 25 & 0 & 0 & 25 \\
\hline $\begin{array}{l}\text { Phage } \\
\text { group M }\end{array}$ & 25 & 0 & 0 & 25 \\
\hline $\begin{array}{l}\text { Bovine mastitis } \\
\text { (collection 2) }\end{array}$ & 0 & 50 & 0 & 50 \\
\hline $\begin{array}{l}\text { Total } \\
\text { Biotype present in }\end{array}$ & $\begin{array}{l}185(71.1) \\
\text { humans }\end{array}$ & $\begin{array}{l}53(20.4) \\
\text { cows }\end{array}$ & $\begin{array}{c}22(8.5) \\
-\end{array}$ & 260 \\
\hline
\end{tabular}

Group I alpha and/or delta haemolytic

Group II beta haemolytic

Figures between brackets are percentage 
Table 2. The biocharacteristics of 3 groups of $S$. aureus representing different sources.

\begin{tabular}{lcccr}
\hline & \multicolumn{4}{c}{ Number of isolates tested } \\
\cline { 2 - 5 } Characteristics & $\begin{array}{c}\text { Bovine } \\
\text { collection 1 }\end{array}$ & $\begin{array}{c}\text { Human } \\
\text { collection }\end{array}$ & $\begin{array}{c}\text { Bovine } \\
\text { collection 2 }\end{array}$ & Total \\
\hline Coagulation: & & & & \\
$\quad$ Human plasma & 110 & 100 & 50 & 260 \\
$\quad$ Bovine plasma & 18 & 0 & 50 & 68 \\
$\begin{array}{l}\text { Fibrinolysin: } \\
\text { (human plasma) }\end{array}$ & & & & \\
$\quad$ Positive & 82 & 97 & 0 & 179 \\
$\quad$ Negative & 28 & 3 & 50 & 81 \\
$\begin{array}{l}\text { Crystal violet: } \\
\text { A/B }\end{array}$ & 15 & 6 & 50 & 71 \\
$\quad$ C/D & 95 & 94 & 0 & 189 \\
Hemolysin: & & & & \\
$\quad \begin{array}{l}\text { alpha } \\
\text { alpha delta }\end{array}$ & 8 & 36 & 0 & 44 \\
$\quad$ delta & 72 & 60 & 0 & 132 \\
$\quad \begin{array}{l}\text { alpha beta delta } \\
\text { beta }\end{array}$ & 15 & 4 & 0 & 19 \\
Phage typing with & 3 & 0 & 4 & 7 \\
group IV* & 12 & 0 & 46 & 58 \\
\hline
\end{tabular}

* This group is represented by phage $42 \mathrm{D}$ only.

Presumptive identifications of S. aureus biotypes and the non-allotted isolates

The plasma crystalviolet medium was used to detect these biotypes and the non-allotted group of isolates. The 260 isolates could be subdivided with this method and the patterns are shown in Table 4.

The human biotype (group 1) showed fibrinolysis on the human plasma crystalviolet (Hpcv) agar. However, on the bovine plasma crystal violet (Bpcv) agar no fibrinolysis was recorded. Their staining characteristics were shown to be of the crystalviolet type C/D (Table 4).

The bovine biotype (group 2), was found to be non fibrinolytic on both Hpcv and Bpcv agar plates, the crystalviolet type was found to be variable.

The non-alloted isolates (group 3), showed fibrinolysis in both Hpcv and Bpcv agar plates, however, some of these strains showed a consideration zone around the inoculum on the Hpcv agar plate rather than the expected clearance. These strains belonged to phage groups I and III of the human phage set and their crystalviolet type was also variable (Table 4).

\section{Discussion}

This study showed that within the selected alpha and/or delta haemolytic isolates from bovine mastitis (collection 1) $77.3 \%$ of the 
Table 3. Frequency of phage patterns of the bovine collection 1 isolated.

\begin{tabular}{lrl}
\hline $\begin{array}{l}\text { Pattern } \\
\text { number }\end{array}$ & Frequency & * Phage pattern \\
\hline 1 & 2 & $29+$ \\
2 & 4 & $29 / 52 \mathrm{~A}+$ \\
3 & 3 & $52 \mathrm{~A}+$ \\
4 & 2 & $29 / 77+$ \\
5 & 6 & $29 / 52 \mathrm{~A} / 77+$ \\
6 & 1 & $77+$ \\
7 & 3 & $54+$ \\
8 & 4 & $84 / 90$ \\
9 & 3 & 95 \\
10 & 15 & $29 / 6 / 47 / 52 / 54 / 75 / 77 / 81 / 84 \times 85 \times 93 \times 89+$ \\
11 & 10 & $29 / 52 \mathrm{~A} / 6 / 47 / 53 / 54 / 75 / 77 / 84 / 85 / 93 / 89+$ \\
12 & 16 & $29 / 52 / 52 \mathrm{~A} / 80 / 77 / 84 / 93+$ \\
13 & 7 & $6 / 47 / 53 / 54 / 75 / 77 / 84 / 85 / 93+$ \\
14 & 14 & $6 / 42 \mathrm{E} / 47 / 54 / 75 / 77 / 81+$ \\
15 & 12 & $6 / 47 / 53 / 54 / 75+$ \\
16 & 3 & $42 \mathrm{D}$ \\
17 & 5 & non-typable \\
\hline Total & 110 & \\
\hline
\end{tabular}

* Phage-typing done at the State Serum Institute, Denmark.

Table 4. Characteristics of two biotypes and the non-allotted isolates of $S$. aureus on the plasma crystalviolet agar media.

\begin{tabular}{lccc}
\hline $\begin{array}{l}\text { S. aureus } \\
\text { groups }\end{array}$ & $\begin{array}{c}\text { Number } \\
\text { tested }\end{array}$ & $\begin{array}{c}\text { Human plasma } \\
\text { crystalviolet } \\
\text { Hpcv-medium }\end{array}$ & $\begin{array}{c}\text { Bovine plasma } \\
\text { crystalviolet } \\
\text { Bpcv-medium }\end{array}$ \\
\hline $\begin{array}{l}\text { Group 1: } \\
\text { biotype A }\end{array}$ & 185 & $\mathrm{HF}+, \mathrm{CV}-\mathrm{C} / \mathrm{D}$ & $\mathrm{BF}-, \mathrm{CV}-\mathrm{C} / \mathrm{D}$ \\
$\begin{array}{l}\text { Group 2: } \\
\text { biotype C }\end{array}$ & 53 & $\mathrm{HF}-, \mathrm{CV}-\mathrm{A} / \mathrm{B}^{*}$ & $\mathrm{BF}-, \mathrm{CV}-\mathrm{A} / \mathrm{B}^{*}$ \\
$\begin{array}{l}\text { Group 3: } \\
\text { (non-allotted) }\end{array}$ & 22 & $\mathrm{HF}+, \mathrm{HF}^{* *}, \mathrm{CV}-\mathrm{V}$ & $\mathrm{BF}+, \mathrm{BF}-, \mathrm{CV}-\mathrm{V}$ \\
\hline Total & 260 & & \\
\hline
\end{tabular}

HF+: Fibrinolytic to human plasma, BF+: Fibrinolytic to bovine plasma, CV/C/D: violet, CV-A/B: yellowish-white, HF-: non-fibrinolytic to human plasma, BF-: non-fibrinolytic to bovine plasma. HF**: Condensation zone on human plasma medium around the growth instead of clearance. CV-A/B*: mostly A/B type, but could be variable. 
strains studied were found to be of the human biotype A and $20 \%$ were of intermediate types, originating from humans as indicated by their phage patterns and fibrinolytic abilities on human plasma. Only $2.7 \%$ of strains were of the bovine biotype $\mathrm{C}$. The incidence of Biotype $\mathrm{A}$ in this group was high in numbers as compared with the results of other authors (Hajek \& Marsalek 1971, Marsalek \& Hajek 1973, Adekeye 1980). This could be explained by the selection of those strains producing alpha and/or delta lysins which were found to be phenotypic characteristics of the human isolates of S. aureus (Miljkovic et al. 1974, Elias \& Köfer 1980).

While the non-alloted strains showed reactions characteristics of both biotypes, collection 2 strains isolated from mastitis cases however, showed the biological characteristics of the bovine biotype C. This is expected according to Hajek \& Marsalek (1970) who attributed $89.1 \%$ of the cause of staphylococcal mastitis to $S$. aureus variety bovis which is the bovine biotype $\mathrm{C}$ of $\mathrm{Ha}$ jek \& Marsalek (1971). These strains were used in this study as a negative control.

As a positive control, strains of the human collection (the phage-typed human isolates) were found to belong to the human biotype A irrespective of their phage group. This is in agreement with the characteristic of the human isolates of $\mathrm{S}$. aureus reported by $\mathrm{Ha}$ jek \& Marsalek (1971), Marsalek \& Hajek (1973), Rische (1973), Elias \& Köfer (1980), Adekeye (1980), Devriese (1984).

The present study supports the subdivision of $S$. aureus into host-specific biotype, and that the biotyping system could be used in the differentiation of ecologically different strains of $S$. aureus.

A combination of human or bovine plasma and crystalviolet agar was used to give presumptive differentiation between human and bovine biotypes and even to detect the intermediate strains originating from humanbeings which were involved in bovine mastitis. This is due to the fact that the fibrinolysin reaction was exhibited by only the human strains (eventhough not as yet unambiguous), where as the bovine strains were found to be negative (Christie \& Wilson 1941, Meyer 1967, Hajek \& Marsalek 1970, Marsalek \& Hajek 1973, Rische 1973, Adekeye 1980, Devriese 1984). However, our study found that there was more specificity by the human strains of $S$. aureus towards lysing the human fibrin even though not conclusive as complicated due to reactions shown by the non-allotted isolates, hence the above criterion was used as a presumptive and not conclusive one.

It was also noted that the behavior of these fibrinolytic strains on human plasma crystal plates and bovine plates could indicate the level of adaption of these strains in the bovine. These strains may acquire fibrinolysis of bovine plasma with a corresponding zone of condensation on the human plasma crystalviolet plates or keep abilities of fibrinolysis of both plasmae. The crystalviolet type can also differentiate some phenotypic characteristics of these biotypes in their relation to bovine mastitis (Klastrup 1955, Meyer 1967). This phenomenon could be used to establish as to how recent or old the infection originated from the human sources, which would obviously be a very useful finding with regards to the epidemiology of bovine mastitis (Table 4 ).

The negative control (collection 2), behaved in a completely different manner by showing the crystalviolet type A/B or possibly variable type, and being fibrinolysin-negative on both plasmae. The fact that these strains were adaptated to the bovine, had lived and continued to live in balance with their host whereby the production of their fibrinolysis 
enzymes with their host whereby the production of their fibrinolysis enzymes was rendered unnecessary in this case (Table 4).

The positive control group behaved in accordance with the human biotype on the $\mathrm{Hpcv}$ plates and bore a negative relationship to the bovine host with regards to the possibility of adaption.

The phage patterns indicated the human origin of the biotype $\mathrm{A}$ and the non-allotted strains of $S$. aureus as isolated from bovine mastitis in Denmark (Table 3).

In conclusion, isolation of alpha and/or delta haemolytic strains of $S$. aureus from bovine mastitis will call for further investigation as to the source of infection which will undoubtedly help the investigator to control the problem and alleviate the chronicity of staphylococcal mastitis being a continuing problem. This study may prove useful to pilot an extensive epidemiologic study with regards to the sources of infections due to $S$. aureus in man and animals.

\section{Acknowledgements}

This work was supported by FAO/DANIDA under the administration of the Development Cooperation Bureau, Copenhagen, Denmark.

We are very grateful to Dr. K. Rosendal of the Department of Hospital Infections, SSI, Denmark, for phage-typing the bovine mastitis isolates and providing the phage-typed human strains.

\section{References}

Adekeye D: Enterotoxin production by strains of Staphylococcus aureus isolated from animals and man in Nigeria. Vet. Microbiol. 1980, 5, 143-150.

Baird-Parker AC: The classification of Staphylococci and Micrococci from world-wide sources. J. gen. Microbiol. 1965, 38, 363-387.

Blair JE, Williams REO: Phage-typing of Staphylococci. Bull. Wld. Hlth. Org. 1961, 24, 777-784.

Christie $R$, Wilson $H$ : A test for staphylococcal fibrinolysin. Austr. J. exp. Biol. 1941, 19, 329.
Cruickshank R, Duguid JP, Mamion BP, Swain PHA: Medical Microbiology 12th ed. Vol. 2. The practice of Medical Microbiology. Churchill Livingstone, Edingburgh, London and New York 1975.

Devriese LA, Oeding $P$ : Characteristics of Staphylococcus aureus strains isolated from different animal species. Res. Vet. Sci. 1976, 21, 284-291.

Devriese LA: A simplified system for biotyping Staphylococcus aureus strains isolated from different animal species. J. appl. bacteriol. 1984, 56, 215-220.

Elias B, Köfer J: Staphylococcus aureus haemolysins their use in strain typing. Acta Microbiol. Acad. Sci. Hungary 1980, 27, 183-190.

Hajek V, Marsalek E: A study of Staphylococci of bovine origin. Staphylococcus aureus var. bovis. Zbt. Bakt. I. Abt. Orig. A. 1972, 26, 154-160.

Hajek $V$, Marsalek $E$ : The differentiation of patogenic staphylococci and a suggestion for their taxonomic classification. Zbt. Bakt. I. Abt. Orig. A. 1971, 217, 176-182.

Israel L: In The Staphylococci. Cohen JO (Ed.) page 443-456. Willey-Interscience. New YorkLondon-Sydney-Toronto 1972, pp 443-456.

Janzen JJ: Economic losses resulting from mastitis. J. Dairy Sci. 1970, 53, 1151-1161.

Klastrup $O$ : Crystalviolet agar for the differentiation of staphylococci isolated from aseptically drawn milk samples. Preliminary communication. Nord. Vet. Med. 1955, 7, 315-320.

Marsalek E, Hajek $V$ : The classification of pathogenic staphylococci. Contributions to microbiology and immunology. Vol. 1. Staphylococci and Staphylococcal infections. Karger, Basel 1973, pp 30-37.

Meyer $W$ : A proposal for subdividing the species of Staphylococcus aureus. Int. J. Syst. Bacteriol. 1967, 17, 387-389.

Miljkovik V, Ranisavljevic M, Stojanovic L, Mijacevic $Z$ : Some characteristics and interaction of staphylococcal haemolysis isolated from cow milk. Acta Veterinaria (Beograd) 1974, 24, No. 2, 42-53.

Mohan K, Pal SC: Reciprocal transmission of Staphylococcus aureus between man and ani- 
mals. J. Communicable Diseases 1973, No. 4, 186-189.

Rische $H$, Meyer $W$, Tschape $W$, Zome VD, Hummel R: The taxonomy of Staphylococcus aureus. Contributions to microbiology and immunology Vol 1. Staphylococci and Staphylococcal Infections 1973, pp 24-29. Krager, Basel.

Subcommunitee on Taxonomy of Staphylococci and Micrococci. Recommendations. Int. Bull. Bact. Taxonomy \& Nomenclature 1965, 15, 109-110.

Witte W, Grigorova M, Bajljosov D, Hummel R, Koruko VG: Ecology og Staphylococcus aureus. Comparative characterization of strains isolated from man, cat, sheep in Bulgaria and German Democratic Republic. J. Hyg. Epid. Microbiol. and Immunol. 1978, 22, No. 2, 177-183.

\section{Sammendrag}

Sammenlignende beskrivelse og typebestemmelse af humane og bovine isolater af Staphylococcus aureus.

110 alfa- og/eller deltahæmolytiske stammer (ind- samling 1), 50 betahæmolytiske stammer (indsamling 2) fra mastitis hos kvæg og 100 tidligere fagtypede alfa- og deltahæmolytiske stammer (human indsamling) af Staphylococcus aureus blev undersøgt og biotypet efter Hajek og Marsaleks metode (1971).

$85(77,3 \%)$ af stammerne i indsamling 1 tilhørte den humane biotype A (human oprindelse); 22 $(20 \%)$ såkaldte vilde stammer viste egenskaber hidrørende fra både animalske og humane kilder. de øvrige 3 isolater $(2,7 \%)$ i denne indsamlingsgruppe tilhørte biotype $\mathrm{C}$ (animalsk oprindelse).

Alle 50 isolater $\mathrm{i}$ indsamling 2, der blev brugt som kontrolstammer for animalske kilder, tilhørte biotype C.

Den tredje gruppe, der indeholdt 100 fagtypede hæmolytiske stammer (repræsenterende alle humane faggrupper), blev anvendt som kontrol for human oprindelse. Uanset faggruppe producerede disse stammer hovedsageligt alfa- og/eller deltahæmolysiner og tilhørte den humane biotype A.

Denne undersøgelse viser tillige, at anvendelse af kombineret plasma-krystalviolet-agarsubstrat kan anbefales til foreløbig identifikation af $S$. aureus biotyper.

(Received April 23, 1987; accepted January 4, 1988).

Reprints may be requested from: Kaj Bruhn, Development Cooperation Bureau, Royal Veterinary and Agricultural University, Bülowsvej 13, DK-1870 Frederiksberg C, Denmark. 